\author{
Jan Bartholdy \\ Aarhus School of Business \\ Glenn W. Boyle \\ New Zealand Institute for the Study of Competition and Regulation \\ Roger D. Stover \\ Iowa State University
}

23 March 2004

* We are particularly grateful to Carsten Tanggård for providing us with the data used in this study. We also appreciate the helpful comments we received from Louis Ederington, David Mayes, Vivien Pullar, and two anonymous EJF referees.

Communications to: Jan Bartholdy, Aarhus School of Business, Department of Finance, Fuglesangs Alle 4, 8210 Aarhus V., Denmark, FAX: +45 86151943, e-mail: jby@asb.dk 
DEPOSIT INSURANCE AND THE STOCK MARKET: EVIDENCE FROM DENMARK

\begin{abstract}
Previous studies of the relationship between deposit insurance and bank market values have usually been limited to consideration of minor changes in bank regulations, but the 1987 initiation of deposit insurance in Denmark permits examination of a potentially major policy shift. We find that the market values of large Danish banks exhibited a modest positive reaction to the announcement of insurance, but that small risky banks responded negatively. These results partially contrast with those previously found for the United States, an outcome that seems likely to reflect the interaction of deposit insurance with the particular characteristics of the pre-existing Danish regulatory system.
\end{abstract}

Keywords: Deposit insurance, Bank regulation, Denmark 


\section{DEPOSIT INSURANCE AND THE STOCK MARKET: EVIDENCE FROM DENMARK}

\section{INTRODUCTION}

A fundamental question for banking researchers is whether deposit insurance has wealth implications for bank stockholders. The evidence to date, primarily from studies of the United States (U.S.) banking system, suggests that shareholders of large or risky banks benefit at the expense of those with holdings in smaller or more conservatively managed institutions. However, this conclusion is derived from observing incremental changes in the U.S. system and, therefore, is of questionable generality for banks outside the U.S. ${ }^{1}$

A useful example of a more significant change in depositor protection policy is provided by Denmark. On 16 December 1987, the Danish Parliament legislated the adoption of a new deposit insurance fund. Prior to this date, the Danish banking authorities had adopted a highly predictable merge-and-close policy with respect to troubled banks. In contrast to the U.S., Danish policy at that time consisted of a coordinated enforcement of both minimum capital standards and a strict bank closure rule. ${ }^{2}$ In addition, Danish banks employed a mark-to-market accounting system that enhanced outside monitoring by various stakeholders. As Pozdena (1992) notes, such a system was fundamentally different to that of the U.S. and had resulted in an orderly disposition of weak banks at low cost to banking authorities

In this paper, we examine the stock market reaction of Danish banks to that country's introduction of deposit insurance. We focus first on the banking sector as a whole, as this reflects the market's assessment of the likely adjustments in overall regulatory policy. If the market expected no change in regulatory oversight, then the introduction of deposit insurance may lower bank funding costs (see Bartholdy et al, 2003), but should otherwise have

1 For example, Duan et al (1992) are restricted to looking at the 1981 change in capital requirements in their assessment of the role of deposit insurance in bank investment decisions.

2 Stover (1997) argues that the Early Resolution Program followed by the U.S. Resolution Trust Corporation in the early 1990s accomplished a similar result, but only for a very limited number of institutions. As in Denmark, the RTC attempted to intervene while the failing institution still had positive net worth. 
little impact and therefore induce only a small effect on the stockmarket value of the banking sector. By contrast, if Danish regulators were expected to adopt a more relaxed policy, then bank shareholders should benefit, particularly if the insurance scheme contained implicit "toobig-to-fail" provisions.

Motivated by U.S. evidence showing that the wealth effects of changes in bank regulatory policy can differ across banks, we also calculate the market reaction for various bank sub-groups based on size and risk. ${ }^{3}$ If the introduction of deposit insurance was expected to result in weaker regulatory oversight, then large banks and risky banks should gain the most. Large banks can take more risks, but are too big to be allowed to fail; risky banks not only extract significant protection benefits, but also obtain additional opportunities to trade their way out of financial difficulties. On the other hand, if no change in regulator behavior was anticipated, then the gain to large banks should be less (because they cannot benefit from more liberal oversight) while risky banks could potentially lose (because they no longer need to be rescued in order to protect depositors).

Using data from the 49 listed Danish banks, we find that the introduction of deposit insurance had a modest positive impact on the market value of the Danish banking sector, although this response is statistically significant only for large banks. We also find that, among small banks, the high-risk institutions experienced a negative reaction, a finding that differs from conventional wisdom, but one that seems likely to reflect the nature of the preexisting Danish regulatory system and the expected response of this system to the presence of a deposit insurance fund.

In the next section we summarise the events leading up to the Danish adoption of deposit insurance and identify the key events on which we subsequently focus. Section 3 describes our data and outlines our hypotheses and methodology. Section 4 contains our results, while section 5 summarizes our findings and provides some concluding remarks.

3 For examples of the U.S. evidence, see O'Hara and Shaw (1990) and Cornett and Tehranian (1990). 


\section{THE DANISH BANKING SYSTEM AND THE INTRODUCTION OF DEPOSIT INSURANCE}

The potentially negative effects of deposit insurance can be mitigated by other aspects of bank regulatory policy. Higher capital requirements force stockholders to bear some of the risk of management decisions, while strict closure rules reduce the risk-taking incentives offered by deposit insurance. ${ }^{4}$ However, when regulators fail to consistently enforce bank discipline, problems can arise, e.g., the thrift institution crisis in the U.S. during the later 1980s. As Kane (1985) notes, the principal characteristics of the U.S. system during that period - non risk-adjusted deposit insurance coupled with significant regulatory forbearance - resulted in a shifting of wealth from small banks to large banks and from wellcapitalized institutions to risky institutions.

Any examination of the introduction of deposit insurance in Denmark must therefore be conditioned by the market perception of that country's existing regulatory system. Furthermore, any comparison of our results with those of other studies that have concentrated on the U.S. banking system must also recognize the essential differences in the two systems. To facilitate such comparisons, and thus assist interpretation of our results, we first describe the essential characteristics of the Danish regulatory system.

\subsection{The Danish Regulatory System}

During the post-World War II period, the Danish regulatory system has been consistently predictable in its emphasis on capital adequacy and prompt closure of troubled banks. This approach was most recently mandated by the 1974 Commercial Banks and Savings Banks Consolidated Act. Under this Act, the Danish Inspectorate of Commercial and Savings Banks (known as the Finanstilsynet) serves as the regulatory agency under the auspices of the Ministry of Economics and Industry. The latter has the power to both issue and revoke bank charters. In the late 1980s, this system required banks to maintain a capital/assets ratio equal to $8 \%$ of total debt and guarantees. If a bank's capital ratio dropped

4 Studies that document these incentives include Duan et al (1992), Billett et al (1998), Pyle (1986), Ronn and Verma (1986), Kane (1989), and Pennachi (1987). 
below this threshold, then part of its profits had to be diverted to a statutory reserve. Failure to satisfy these standards resulted in severe sanctions; at a $6 \%$ capital/assets ratio, the bank had to seek additional capital from the markets. If it could not do so, closure was imminent. The effect of this system was to give weak banks an incentive to find a viable merger partner, since the alternative was closure and loss of capital. According to Pozdena (1992), the Danish legal system both facilitated mergers and allayed any possible anti-trust objections. Consequently, only one Danish bank had faced bankruptcy between the end of World War II and 1987, the year when the deposit insurance proposal first emerged.

Complementing this rigid regulatory policy was Denmark's use of mark-to-market accounting. ${ }^{5}$ Danish financial institutions were required to provide for valuation adjustments in their respective asset portfolios caused by interest rate, exchange rate, and credit risk factors. Such requirements were not trivial in that as much as $30 \%$ of Danish bank assets were held in the form of stocks and bonds. As a result, this feature of the Danish system not only provided regulators with an effective means of assessing the risk of insolvency, but also facilitated outside monitoring by shareholders and other stakeholders.

\subsection{Deposit Insurance Legislation}

Table 1 details the principal events leading up to the adoption of deposit insurance in Denmark. On 22 December 1986, the European Economic Community (EEC) recommended that those member countries without a deposit insurance system establish such a programme. While this proposal represented the EEC's official position, a summary did not appear in the Danish press until 4 February 1987 when a summary was published in De Europceiske Fallesskabers Tidende. On 28 October 1987, after negotiations with various banking organizations and the Danish Central Bank, the Ministry for Industry put forward a bill to Parliament for a Deposit-Guarantee Fund.

5 By contrast, financial institutions in the U.S. were principally required to produce historical-cost book value statements. Bernard et al (1995) detail how the two systems compare in the context of their overall regulatory structures. 


\section{[Insert Table 1 About Here]}

The bill proposed the establishment of a fund covering deposits of commercial banks, savings banks, cooperative banks, and branches of foreign banks in Denmark, and certain credit institutes with special authorization (e.g., banking houses) in the event of bankruptcy. The financing of the program was to be based on deposits and, if needed, guarantees from the covered financial institutions. Each institution was to be assessed a maximum of two-tenths of $1 \%$ of total deposits. The proposal limited general deposit coverage to Kr. 250,000 with exceptions promised for deposit accounts held for pension purposes, children's savings accounts, and certain other categories. While discussion in Parliament focused on protecting small depositors, the proposed system did not specify a maximum loss. Thus, it provided de facto total coverage of all depositors up to the Kr. 250,000 limit. Finally, if the fund were found to be inadequate to cover a larger bankruptcy, then the proposed regulations permitted the fund to borrow to cover the shortfall. The Danish government would guarantee such loans.

\section{DATA AND EMPIRICAL HYPOTHESES}

\subsection{Data}

We use daily stock returns of all 49 banks listed on the Københavns Fondsbørs, henceforth referred to as the Copenhagen Stock Exchange (CSE), between 1 January 1986 and 22 March 1988. These data were obtained from the Aarhus School of Business, as were the daily return data for (i) the value-weighted index of all stocks listed on the CSE and (ii) the value weighted index of all bank stocks listed on the CSE. In addition, we obtained size and ratio data for each bank from the 1987 Finanstilsynet annual report.

To allow for the possibility that the market reaction differed across banks, we create size-based sub-samples of our bank stocks. For this purpose, we use the three size groups defined by the Finanstilsynet. This categorization is based on a bank's share of the banking system's total active capital (deposits + debt + equity) and distinguishes between banks as follows: 


$\begin{array}{ll}\text { Large banks: } & \text { at least } 4 \% \text { of active capital } \\ \text { Medium banks: } & \text { between } 0.3 \% \text { and } 4 \% \text { of active capital } \\ \text { Small banks: } & \text { no more than } 0.3 \% \text { of active capital }\end{array}$

Table 2 provides some descriptive statistics for Danish banks during the sample period. At the end of 1987, the large banks in our sample were, on average, 13 times the size of medium banks, which were, in turn, seven times as large as the small banks. The mean equity/asset ratios ranged from $5.9 \%$ for the large bank category to $11.5 \%$ for the smallest banks. ${ }^{6}$ Similarly, small banks were the most profitable. Shareholder returns were negative in all categories during the sample period.

\section{[Insert Table 2 About Here]}

\subsection{Hypotheses}

The market response to the introduction of a new deposit insurance scheme seems likely to depend primarily on its expected impact on regulator behaviour. In particular, as Podzena (1992) observes, a deposit insurance fund can buffer the pressure on bank regulators and thus lead to less diligent monitoring of bank capital. In the specific case of Denmark, the introduction of deposit insurance provided Danish banking regulators with an opportunity to relax their former rigid merger-and-close policy. Given the experience of other countries in which deposit insurance co-existed with an often-slack regulatory policy, Danish investors could reasonably anticipate that the deposit insurance fund would substitute for aggressive regulation. As a result, banks would be able to shift risk from themselves to taxpayers and reap the benefits of the associated wealth transfer. Thus, our first hypothesis is that the introduction of deposit insurance was associated with an upward revision of banking sector value.

6 Equity capital only is employed in the numerator of these ratios. They should not be confused with the total capital/assets ratio used in the Danish regulatory insolvency determination. Banks are permitted to use other liabilities in achieving the minimum regulatory capital requirements. 
Even if the introduction of deposit insurance had no effect on the banks in aggregate, this leaves open the possibility that some banks gained while others lost. For example, O'Hara and Shaw (1990) suggest that the market reaction to changes in deposit insurance coverage differs according to bank size because of the "too-big-to-fail" effect. Similarly, Cornett and Tehranian (1990) find that the 1982 passage of the Garn-St. Germain Depository Institutions Act was associated with positive abnormal returns for large banks, but negative abnormal returns for small banks. In the Danish case considered here, large banks may be expected to gain at the expense of small banks for two principal reasons. First, the previous merger-and-close policy required large banks to bail out troubled small banks. Although such mergers had generally been undertaken on attractive terms to the acquiring bank, the risk remained that at any future time a large bank could be required to rescue one or more small banks at a significant financial cost. $^{7}$ To the extent that the introduction of deposit insurance suggested that troubled banks would be closed rather than merged, this risk was reduced and large banks could be expected to benefit. Second, the costs associated with the deposit insurance scheme seemed likely to fall disproportionately on small banks. For example, if a large bank failed and additional fund borrowing was required to finance the payout to depositors, then small banks could expect to bear part of the costs in the form of higher future premiums. By contrast, failure of a small bank would have only a negligible effect on the future premiums of large banks. Such an asymmetric imposition would, moreover, be exacerbated by the implicit adoption of a "too-big-to-fail" provision in the insurance scheme. For these reasons, our second hypothesis is that the introduction of deposit insurance was associated with a greater increase in the value of large banks.

Deposit insurance also offers two opportunities for high-risk banks to gain relative to low-risk banks. First, the bankruptcy protection benefits are more significant for the former, thereby providing them with a greater reduction in the cost of deposits. Second, to the extent that the introduction of deposit insurance implied a more relaxed regulatory policy, then risky banks could expect to be granted more latitude than previously and thereby benefit from

7 Indeed, discussions with market participants suggest that such fears were on the rise at this time due to increased licensing of risky banks during the 1980s. 
increased opportunities to manage their way out of trouble. Thus, our final hypothesis is that the introduction of deposit insurance was associated with a greater increase in the value of high-risk banks than of low-risk banks.

\section{EMPIRICAL RESULTS}

To address our first hypothesis, we regress the daily bank index return on the market return and on dummy variables corresponding to each event listed in Table 1. That is, we estimate

$$
\mathrm{R}_{\mathrm{t}}=\alpha+\beta \mathrm{R}_{\mathrm{mt}}+\sum_{k=1}^{8} \gamma_{k} \mathrm{D}_{k \mathrm{t}}+\varepsilon_{\mathrm{t}}
$$

where

$$
\begin{aligned}
& \mathrm{R}_{\mathrm{t}}=\text { day } t \text { return on the value-weighted index of Danish banking stocks } \\
& \mathrm{R}_{\mathrm{mt}}=\text { day } t \text { return on the value-weighted Danish stock market index } \\
& \mathrm{D}_{k \mathrm{t}}=1 \text { if day } t \text { corresponds to event } k \text { in Table } 1 \text {, and } 0 \text { otherwise }
\end{aligned}
$$

and $\gamma_{k}$ denotes the abnormal return associated with event day $k$.

Ordinary Least Squares estimation of equation (1) yields ( $t$-statistics in parentheses)

$$
\begin{aligned}
& \mathrm{R}_{\mathrm{t}}=-0.005+0.99 \mathrm{R}_{\mathrm{mt}}-0.59 \mathrm{D}_{1 \mathrm{t}}+0.13 \mathrm{D}_{2 \mathrm{t}}+1.70 \mathrm{D}_{3 \mathrm{t}}-0.25 \mathrm{D}_{4 \mathrm{t}} \\
& \begin{array}{lllll}
(0.22) \quad(40.0) \quad(1.10) \quad(0.24) \quad(3.15) \quad(0.47)
\end{array} \\
& \text { - } 0.17 \mathrm{D}_{5 \mathrm{t}}-0.01 \mathrm{D}_{6 \mathrm{t}}+0.11 \mathrm{D}_{7 \mathrm{t}}-0.06 \mathrm{D}_{8 \mathrm{t}} \quad \text { Adj. } \mathrm{R}^{2}=0.74 \\
& \begin{array}{llll}
(0.31) & (0.01) \quad(0.21) \quad(0.11)
\end{array}
\end{aligned}
$$

Although bank index returns are independent of most events leading to the adoption of deposit insurance, the introduction on 28 October 1987 of the deposit insurance legislation to Parliament is associated with a $1.7 \%$ abnormal return that is significant at the $1 \%$ level. This provides some evidence that the introduction of deposit insurance was expected to benefit the banking sector, consistent with our first hypothesis that the insurance fund might be used as a substitute for diligent monitoring, thereby permitting banks to obtain risk-enhanced returns. However, as discussed in the previous section, this aggregate effect may conceal considerable inter-bank variations and it is to these issues that we now turn. 
To address our hypothesis regarding differential size-based effects, some refinement of (1) is necessary. In particular, since all our dependent variable data are drawn from firms in the same industry, the error terms are likely to be correlated. To overcome this problem, we estimate the following system of seemingly unrelated regression equations: ${ }^{8}$

$$
\mathrm{R}_{\mathrm{it}}=\alpha_{\mathrm{i}}+\beta_{\mathrm{i}} \mathrm{R}_{\mathrm{mt}}+\beta_{\mathrm{i} 1} \mathrm{R}_{\mathrm{mt}-1}+\beta_{\mathrm{i} 2} \mathrm{R}_{\mathrm{mt}-2}+\sum_{k=1}^{8} \gamma_{\mathrm{i} k} \mathrm{D}_{k \mathrm{t}}+\varepsilon_{\mathrm{it}} \quad \mathrm{i}=1,2,3
$$

where $\mathrm{R}_{\mathrm{it}}$ is the day $t$ stock return on portfolios $\mathrm{i}=1$ (large banks), 2 (medium banks), 3 (small banks). The lagged market returns are included to control for thin trading, particularly in small banks.

The results from estimating (2) appear in Table 3. ${ }^{9}$ Consistent with our second hypothesis, the positive aggregate reaction to the introduction of the deposit insurance legislation to Parliament is entirely attributable to large banks. While they experienced an average abnormal return of $2.205 \%$ on that date, significant at the $1 \%$ level, the abnormal returns for medium and small banks were insignificantly different from zero. ${ }^{10}$ This suggests that the cost and risk changes associated with the deposit insurance scheme were expected to primarily benefit large banks.

\section{[Insert Table 3 About Here]}

Although there is no significant market reaction to any of the remaining events, there remains the possibility that their cumulative effect may be non-zero. To examine this possibility, we calculate $\sum_{\mathrm{j}=1}^{8} \gamma_{i k}$ for each size cohort and compare the differences between

8 For other examples of this approach in similar contexts, see Binder (1985), Cornett and Tehranian (1990), and Wagster (1996).

9 These results are for one-day event dates. Two-day returns yield similar findings.

10 A simple $\chi^{2}$ test confirms that the large-bank reaction was significantly greater than those of medium and small banks. 
them using a test statistic that is asymptotically distributed as $\chi^{2}$ with one degree of freedom. This yields

$$
\begin{array}{ll}
\text { Large banks vs medium banks: } & \chi^{2}=1.833 \text { (significant at } 0.176 \text { level) } \\
\text { Large banks vs small banks: } & \chi^{2}=2.871 \text { (significant at } 0.090 \text { level) } \\
\text { Medium banks vs small banks: } & \chi^{2}=0.087 \text { (significant at } 0.768 \text { level) }
\end{array}
$$

Thus, the cumulative effect of all eight events appears to have had no discernible differential impact on large banks relative to medium banks, or on medium banks relative to small banks, but had a marginally greater impact on large banks relative to small banks. Again, this offers some support for our hypothesis that large banks were expected to be the primary beneficiaries of the deposit insurance scheme. ${ }^{11}$

As large banks are generally less risky than small banks, these results could also be interpreted as implying that riskier banks were expected to benefit less from the introduction of deposit insurance, contrary to conventional wisdom. To investigate this issue further, we focus exclusively on our sub-sample of small banks (since it is amongst these that risk differences are likely to be most apparent) and re-estimate equation (2) for $i=1$ (high-risk banks), 2 (medium-risk banks), 3 (low-risk banks). Measurement of bank risk is a somewhat fraught issue, but we categorise banks according to their capital ratios, since it was these that were monitored by the Finanstilsynet. Those banks with capital ratios in the lower third of our sample are defined as high risk; those in the middle third as medium risk; and those in the upper third as low risk.

Table 4 presents the results of this analysis. Surprisingly, insofar as it contradicts our third hypothesis, the high-risk banks responded negatively to events two (the first publication of the EEC recommendation) and four (the first parliamentary debate) with abnormal returns

11 As the first debate of the legislation on 3 November 1987 indicated a clear majority in favour, it seems possible that the market viewed approval as a foregone conclusion after this date. We therefore reestimate equations (1) and (2) excluding the last four events in Table 1, and obtain similar qualitative results. However, the difference between large and small banks becomes significant at the 5\% level. Similarly, the distinction between high-risk banks and medium/low-risk banks in Table 4 becomes statistically more robust, but is otherwise unaffected. 
of $-2.52 \%$ and $-2.28 \%$, respectively, both significant at the $5 \%$ level. By contrast, neither low-risk nor medium-risk banks responded significantly to any event. ${ }^{12}$

\section{[Insert Table 4 About Here]}

Analysis of the cumulative effect of all eight events again yields similar results

$$
\begin{array}{ll}
\text { High-risk versus medium-risk banks: } & \chi^{2}=5.045 \text { (significant at } 0.025 \text { level) } \\
\text { High-risk versus low-risk banks: } & \chi^{2}=2.777 \text { (significant at } 0.096 \text { level) } \\
\text { Medium-risk versus low-risk banks: } & \chi^{2}=0.038 \text { (significant at } 0.846 \text { level) }
\end{array}
$$

That is, the stock market reaction to the cumulative impact of the deposit insurance legislation was significantly more negative for high-risk small banks than for other small banks.

Overall, these findings suggest that high-risk banks were expected to be adversely affected by the introduction of deposit insurance. This result is at odds with our third hypothesis and seems particularly interesting, in that it contradicts both the conventional wisdom that greater deposit insurance coverage primarily benefits riskier banks, and the U.S. evidence of O'Hara and Shaw (1990) supporting this view.

There are two possible reasons for this unexpected outcome, both of which relate to the interaction between deposit insurance and the prior Danish regulatory policy. First, as discussed earlier, deposit insurance allows regulators to force bank shareholders to endure the consequences of failure, since failing banks no longer need to be rescued in order to protect depositors. ${ }^{13}$ Thus, the introduction of deposit insurance would be associated with greater downside risk for bank shareholders.

Second, the previous merger-and-close policy had permitted early identification of troubled banks, so any required mergers had usually occurred while the acquired bank retained

12 Again, a $\chi^{2}$ test indicates that the reaction among high-risk banks on each of these dates is significantly more negative than those of medium-risk and low-risk banks.

13 Indeed, the original scheme explicitly prohibited the deposit insurance fund from rescuing troubled banks. A subsequent law change allowed regulators to undertake rescue in circumstances where payment of insurance to depositors would be more expensive. 
some positive net worth. Consequently, shareholders of the acquired banks generally emerged with positive equity. By contrast, if a deposit insurance scheme resulted in regulators adopting a less rigorous closure policy, thereby allowing troubled institutions to deteriorate further, the eventual liquidation payment to shareholders would be correspondingly reduced. Thus, to the extent that the substitution of deposit insurance for merger-and-close lowered the probability of regulator intervention, there would be a higher shareholder loss in those states where intervention eventually became necessary. For low-risk and medium-risk banks, this possibility was of little consequence, but it had potentially adverse consequences for high-risk banks. In short, the previous merger-and-close policy provided a mechanism for rescuing the shareholders of troubled banks, but the introduction of deposit insurance raised the possibility that this mechanism might disappear.

\section{CONCLUSION}

Previous empirical research focusing on the role of deposit insurance in a banking system has primarily concentrated on relatively minor alterations in the U.S. scheme. While providing important insight into the managerial effects of that insurance system, such research has been severely limited in its ability to draw generalizable conclusions. The Danish decision to incorporate deposit insurance into a banking system known for mark-to-market accounting and a rigid bank closure procedure provides an opportunity to examine a major change in bank regulation.

Based on the fundamental principle that the market reaction to such a change will reflect its impact on regulator behaviour, we develop three hypotheses. First, because the introduction of deposit insurance offered the potential for lower funding costs and relaxed regulatory oversight, bank share prices should rise. Second, because large banks reaped the greatest benefits while incurring fewer costs, their share prices should rise by more than those of smaller banks. Third, because of greater bankruptcy protection benefits, high-risk banks should gain more than low-risk banks. The results of our analysis support the first two hypotheses, but not the third. In fact, high-risk Danish banks suffered a negative price reaction to the events leading up to the adoption of deposit insurance, a result that contrasts 
with studies of the U.S. system where the general conclusion has been that deposit insurance benefits the more risky banks. This seems likely to reflect the interaction between deposit insurance and the Danish regulatory system, thereby suggesting that arguments concerning deposit insurance systems must be made in the context of a country's overall regulatory structure. 


\section{REFERENCES}

Banker og sparekasser m.v. (1987). Beretning fra Tilsynet med Banker og Sparekasser. Finanstilsynet.

Bartholdy, J., G. Boyle, and R. Stover (2003). Deposit Insurance and the Risk Premium in Bank Deposit Rates. Journal of Banking and Finance, 27 (April), 699-717.

Bernard, V., R. Merton, and K. Palepu (1995). Mark-to-Market Accounting for Banks and Thrifts: Lessons from the Danish Experience. Journal of Accounting Research 33 (Spring), 1-32.

Billett, M., J. Garfinkel, and E. O'Neal (1998). The Cost of Market versus Regulatory Discipline in Banking. Journal of Financial Economics 48, 333-358.

Binder, J. (1985). On the Use of the Multivariate Regression Model in Event Studies. Journal of Accounting Research 23 (Spring), 370-383.

Cornett, M. and H. Tehranian (1990). An Examination of the Impact of the Garn-St. Germain Depository Institutions Act of 1992 on Commercial Banks and Savings and Loans. Journal of Finance 45, 95-111.

Duan, J., A. Moreau, and C. Sealey (1992). Fixed-Rate Deposit Insurance and Risk-Shifting Behavior at Commercial Banks. Journal of Banking and Finance 16, 715-742.

Holm-Nielsen, M. and B. W. Fogh (1989), "Retslige Problemer ved anvendelse af Lov om en underskudsgarantifond," Justitia 12(3), pp. 1-70.

Kane, E. (1985). The Gathering Crisis in Federal Deposit Insurance. Cambridge, MA, MIT Press.

Kane, E. (1989). The S\&L Mess: How Did It Happen Again? The Urban Institute Press, Washington, D.C.

O'Hara, M. and W. Shaw (1990). Deposit Insurance and Wealth Effects: The Value of Being "Too Big to Fail." Journal of Finance 45, 1587-1600.

Pennachi, G. (1987). Alternative Forms of Deposit Insurance: Pricing and Bank Incentive Issues. Journal of Banking and Finance 11, 291-312.

Pozdena, R. (1992). Danish Banking: Lessons for Deposit Insurance Reform. Journal of Financial Services Research 5, 289-298.'

Pyle, D. (1986). Capital Regulation and Deposit Insurance. Journal of Banking and Finance 10, 189-201.

Ronn, E. and A. Verma. (1986). Pricing Risk-Adjusted Deposit Insurance: An Option-Based Model. Journal of Finance 41, 871-895.

Stover, R. (1997). Early Resolution of Troubled Financial Institutions: An Examination of the Accelerated Resolution Program. Journal of Banking and Finance 21, 11791194.

Wagster, J. (1996). Impact of the 1988 Basle Accord on International Banks. Journal of Finance 51, 1321-1346. 
Table 1. Events leading to the establishment of the Danish Deposit Insurance System

\begin{tabular}{|c|c|c|}
\hline Event & Date & Description \\
\hline 1 & December 22, 1986 & $\begin{array}{l}\text { European Economic Community (EEC) suggests that all } \\
\text { member countries should have financial institution deposit } \\
\text { insurance }\end{array}$ \\
\hline 2 & February 4, 1987 & $\begin{array}{l}\text { First date the EEC suggestion was published in De } \\
\text { Europceiske Faellesskabers Tidende }\end{array}$ \\
\hline 3 & October 28, 1987 & $\begin{array}{l}\text { Deposit insurance legislation introduced to Danish } \\
\text { Parliament }\end{array}$ \\
\hline 4 & November 3, 1987 & $\begin{array}{l}\text { Legislation first debated in Parliament and referred to } \\
\text { standing committee with responsibility for banking } \\
\text { legislation }\end{array}$ \\
\hline 5 & December 3, 1987 & Standing committee reports back \\
\hline 6 & December 10, 1987 & $\begin{array}{l}\text { Second debate and standing committee recommendations } \\
\text { are approved }\end{array}$ \\
\hline 7 & December 16, 1987 & $\begin{array}{l}\text { Parliament passes the legislation with } 116 \text { members for it } \\
\text { and } 10 \text { against }\end{array}$ \\
\hline 8 & February 25,1988 & The deposit insurance law goes into effect \\
\hline
\end{tabular}

Source: M. Holm-Nielsen and B. W. Fogh (1989). 
Table 2. Descriptive Statistics for Danish banks: This table shows means and standard deviations (in parentheses) of variables describing the 49 banks in our sample. Size and ratio data are for the year ending 31 December 1987 . Daily shareholder returns are calculated for the period 1 January 1986 to 22 March 1988. Large banks are those with at least $4 \%$ of the system's active capital; medium banks have between $0.3 \%$ and $4 \%$; small banks have less than $0.3 \%$.

\begin{tabular}{|c|c|c|c|}
\hline Variable & Large Banks & Medium Banks & Small Banks \\
\hline $\begin{array}{l}\text { Asset Size } \\
\text { (billion Danish Kr) }\end{array}$ & $\begin{array}{l}83.51 \\
(39.59)\end{array}$ & $\begin{array}{l}6.60 \\
(5.45)\end{array}$ & $\begin{array}{l}0.89 \\
(0.50)\end{array}$ \\
\hline $\begin{array}{l}\text { Equity/Assets } \\
(\%)\end{array}$ & $\begin{array}{l}5.90 \\
(0.20)\end{array}$ & $\begin{array}{l}7.80 \\
(3.00)\end{array}$ & $\begin{array}{l}11.5 \\
(11.72)\end{array}$ \\
\hline $\begin{array}{l}\text { Advances/Deposits } \\
(\%)\end{array}$ & $\begin{array}{l}89.10 \\
(11.00)\end{array}$ & $\begin{array}{l}108.40 \\
(18.50)\end{array}$ & $\begin{array}{l}93.10 \\
(18.10)\end{array}$ \\
\hline $\begin{array}{l}\text { Net Income/Revenues } \\
(\%)\end{array}$ & $\begin{array}{l}2.86 \\
(0.42)\end{array}$ & $\begin{array}{l}3.67 \\
(8.80)\end{array}$ & $\begin{array}{l}4.26 \\
(6.50)\end{array}$ \\
\hline $\begin{array}{l}\text { Shareholder Returns } \\
(\%)\end{array}$ & $\begin{array}{l}-0.05 \\
(1.45)\end{array}$ & $\begin{array}{l}-0.04 \\
(2.01)\end{array}$ & $\begin{array}{l}-0.04 \\
(2.53)\end{array}$ \\
\hline
\end{tabular}


Table 3. Abnormal returns of banks on dates leading to the establishment of the Danish deposit insurance system: Size effects. This table reports the abnormal returns for size-based sub-samples of Danish banks at each of the eight events in which a documented step was made towards introduction of deposit insurance. $t$-statistics are in parentheses; $* * *$ denotes significance at the .01 level. For a description of the size categorizations, see Table 2 .

\begin{tabular}{llll}
\hline \multicolumn{1}{c}{ Events } & & Abnormal Returns & \\
& $\begin{array}{l}\text { Large } \\
\text { Size }\end{array}$ & $\begin{array}{l}\text { Medium } \\
\text { Size }\end{array}$ & $\begin{array}{l}\text { Small } \\
\text { Size }\end{array}$ \\
& & & \\
\hline 1. EEC suggest deposit insurance & 0.307 & -0.901 & -0.548 \\
& $(0.466)$ & $(1.195)$ & $(1.023)$ \\
2. EEC suggestion published & 0.384 & 0.477 & -0.716 \\
& $(0.581)$ & $(0.633)$ & $(1.334)$ \\
3. Insurance legislation introduced & $2.205 * * *$ & 1.012 & 0.150 \\
to Parliament & $(3.315)$ & $(1.333)$ & $(0.278)$ \\
4. First parliamentary debate & -0.065 & 0.278 & -0.487 \\
& $(0.100)$ & $(0.369)$ & $(0.911)$ \\
5. Committee report & -0.380 & -0.258 & 0.185 \\
& $(0.577)$ & $(0.343)$ & $(0.346)$ \\
6. Committee recommends approval & 0.001 & 0.349 & -0.422 \\
& $(0.002)$ & $(0.464)$ & $(0.789)$ \\
7. Parliament passes insurance & & 0.188 & -0.327 \\
regulation & $(0.286)$ & $(0.348)$ & $(0.613)$ \\
8. Law goes into effect & -0.081 & -0.019 & 0.021 \\
& $(0.124)$ & $(0.025)$ & $(0.040)$ \\
\hline
\end{tabular}


Table 4. Abnormal returns of small banks on dates leading to the establishment of the Danish deposit insurance system: Risk effects. This table reports the abnormal returns for risk-based sub-samples of small Danish banks at each of the eight events in which a documented step was made towards introduction of deposit insurance. $t$-statistics are in parentheses; ** denotes significance at the .05 level. High-risk banks are those with capital ratios in the lower third of our sample; those in the middle third are medium-risk; and those in the upper third are low-risk.

\begin{tabular}{llll}
\hline & & Abnormal Returns & \\
& High & Medium & Low \\
& Risk & Risk & \\
\hline 1. EEC suggest deposit insurance & -0.700 & 0.412 & -1.295 \\
& $(0.823)$ & $(0.569)$ & $(1.422)$ \\
2. EEC suggestion published & $-2.524^{* *}$ & -0.283 & 0.554 \\
& $(2.907)$ & $(0.394)$ & $(0.604)$ \\
3. Insurance legislation introduced & -0.973 & 1.128 & 0.283 \\
to Parliament & $(1.112)$ & $(1.556)$ & $(0.307)$ \\
4. First parliamentary debate & $-2.275^{* *}$ & -0.469 & 1.146 \\
& $(2.645)$ & $(0.652)$ & $(1.257)$ \\
5. Committee report & 0.290 & -0.068 & 0.321 \\
& $(0.338)$ & $(0.095)$ & $(0.353)$ \\
6. Committee recommends approval & -0.343 & -0.293 & -0.614 \\
& $(0.399)$ & $(0.407)$ & $(0.673)$ \\
7. Parliament passes insurance & -0.064 & -0.100 & -0.780 \\
regulation & $(0.075)$ & $(0.140)$ & $(0.858)$ \\
8. Law goes into effect & 0.287 & -0.169 & -0.048 \\
& $(0.335)$ & $(0.236)$ & $(0.053)$ \\
& & & \\
\hline
\end{tabular}

